\title{
Comparison of Individuals' Fear of COVID-19 Pandemic and Perceived Control in Turkey
}

\section{Türkiye'de Bireylerin COVID-19 Pandemisi Korkusu ve Kontrol Algılarının Karşılaştırılması}

\author{
DSerap Öztürk Altınayak', @Zümrüt Yılar Erkek² \\ 'Ondokuz Mayıs University Faculty of Health Science, Department of Midwifery, Samsun, Turkey, \\ ${ }^{2}$ Tokat Gaziosmanpaşa University Faculty of Health Science, Department of Midwifery, Tokat, Turkey,
}

\begin{abstract}
Objective: This study was conducted to compare individuals' fear of novel coronavirus disease 2019 (COVID-19) pandemic and perceived control.

Material and Method: The sample of this descriptive study comprised 1749 individuals between 18 and 70 years of age living in various provinces in Turkey. Data were collected via an online questionnaire. The "Sociodemographic Information Form," "Fear of COVID-19 Scale (FCV-19S)," and "COVID-19 Perceived Control Scale (CV-19PCS)" were used to collect data for this study.

Results: It was determined that the FCV-19S mean total score of participants was $21.7 \pm 5.8$ and the CV-19PCS mean total score was $35.6 \pm 5$.6. There was a statistically significant correlation between the FCV-19S total score and CV19PCS subdimension total scores, whereas no statistically significant effect of the CV-19PCS total score on the FCV-19S total score was found.
\end{abstract}

Conclusion: The results of the study revealed a partial relationship between the fear of COVID-19 pandemic and perceived control in the Turkish society.

Keywords: COVID-19 pandemic, midwifery, perceived control, fear
Öz

Amaç: Bu araştırma bireylerin COVID-19 pandemisi korkusu ile kontrol algılarının karşılaştıııması amacı ile yapıImıştır.

Gereç ve Yöntem: Tanımlayıcı tasarımda yapılan araştırmanın örneklemini Türkiye'nin çeşitli illerinde yaşayan 18-70 yaş arasındaki 1749 birey oluşturmaktadır. Veriler çevrimiçi anket yolu ile toplanmıştır. Araştırmanın verilerinin toplanmasında "Sosyodemografik Bilgi Formu", "COVID-19 Korkusu Ölçeği (COVID-19 KÖ)" ve "COVID-19 Kontrol Algısı Ölçeği (COVID-19 KAÖ)" kullanılmıştır.

Bulgular: Bireylerin COVID-19 KÖ toplam puan ortalaması

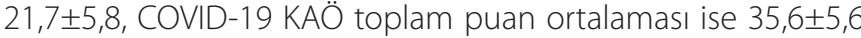
olarak bulunmuştur. COVID-19 KÖ toplam puanı ile COVID-19 KAÖ alt boyut toplam puanları arasında istatistiksel olarak anlamlı bir ilişki bulunurken; COVID-19 KAÖ toplam puanının COVID-19 KÖ toplam puanı üzerine istatiksel olarak anlamlı bi etkisi bulunmamıştır.

Sonuç: Araştırmanın sonuçları doğrultusunda Türk toplumunda COVID-19 pandemisi korkusu ile kontrol algısı arasında kısmen bir ilişki olduğu saptanmıştır.

Anahtar Kelimeler: COVID-19 pandemisi, ebelik, kontrol algısı, korku

Corresponding (IIletişim): Serap Öztürk Altınayak, Assistant Professor, Ph.D. Ondokuz Mayıs University Faculty of Health Science, Department of Midwifery, Kurupelit Campus, 55200, Samsun, Turkey

E-mail (E-posta): serapozturk88@hotmail.com

Received (Geliș Tarihi): 22.05.2021Ａccepted (Kabul Tarihi): 18.08.2021 


\section{INTRODUCTION}

Historically, humanity has had to go through several epidemic diseases, such as plague, Spanish flu, Ebola, and severe acute respiratory syndrome (SARS) ${ }^{[1,2]}$ At present, we are faced with the novel coronavirus disease 2019 (COVID-19) pandemic that emerged in Wuhan, China, and rapidly spread worldwide. ${ }^{[3]}$ While the COVID-19 virus that caused this pandemic results in only mild or moderate symptoms in several individuals, the symptoms of the disease follow a more severe course in the elderly or people with a chronic disease, leading to a large number of deaths worldwide. ${ }^{[4,5]}$

Epidemic diseases not only cause the death of individuals but also negatively impact the lives of individuals as well as societies. In literature, there are reports that epidemic diseases cause fear in the mind of individuals. ${ }^{[2,6-8]}$ The fear that occurs due to the nature of the epidemic can affect an individual's relationships in daily lives. For example, there are reports that individuals who were quarantined on suspicion of having come into contact with a SARS patient would try to keep away from people who would sneeze or cough even weeks after quarantine and also avoid crowded or confined spaces, and public spaces. In addition, individuals who were quarantined and had a psychiatric history reported experiencing anxiety and anger even four or six weeks after the quarantine. ${ }^{[9-11]}$ In the COVID-19 epidemic, people have experienced intense fear due to reasons such as having limited information about the disease, high levels of transmission, serious consequences on health, and lack of treatment. ${ }^{[11]}$

Fear or anxiety experienced during epidemics may not have harmful effects to some extent. ${ }^{[12]}$ However, if the fear reaches an uncontrollable level, individuals may lose their perceived control and become unable to fight the epidemic. Therefore, the "perceived control," defined as "the perceived ability to change important situations or adapt to change," plays an important role in protecting health of individuals. ${ }^{[13,14]}$ In addition, there are reports in literature that the perceived control mitigates the relationship between the severity of COVID-19 and mental health problems. ${ }^{[15,16]}$ In particular, some studies demonstrated that the perceived control significantly affects both life satisfaction and perceived general health. ${ }^{[17,18]}$ Therefore, in the COVID-19 pandemic, determination of how individuals perceive this situation and how they react to the disease is critical for both individuals and public health. In addition, it is important for health authorities to learn more about these behaviors so that they effectively respond to, and be prepared for, epidemics. ${ }^{[19]}$ The knowledge of how midwives, nurses, and other health professionals, who are in close contact with society, function has influenced society and changed health behaviors to protect and promote both individual health and social health during the COVID-19 pandemic, which, in turn, has been critical for safeguarding and improving the health of individuals in particular and society in general.
In the literature review, studies on different topics such as depression, health anxiety, mental health and psychosocial problems, psychological effects of quarantine, and fear and anxiety levels during the COVID-19 pandemic were encountered. ${ }^{[1,8,20-23]}$ However, there has been no study comparing the fear of the COVID-19 pandemic with the perceived control of the pandemic. For this reason, this study was conducted to compare individuals' fear of the COVID-19 pandemic and their perceived control of the pandemic.

\section{MATERIAL AND METHOD}

\section{Study Design and Participants}

The study employed the descriptive design. Accidental sampling method was used in the study. The population of the study consisted of individuals aged between 18 and 70 years living in various provinces of Turkey. The G*Power software (version 3.1.7) was used to determine the sample size of the study. While calculating the sample size, the correlation coefficients in the article titled "The reliability and validity of Turkish version of coronavirus anxiety scale" were taken into consideration and it was found that the study should be conducted with a minimum of 75 participants with a confidence level of $95 \%(1-\alpha)$, test power of $95 \%(1-\beta)$, and effect size of $\rho=0.4 .^{[24]}$

Data were collected using Google Forms between November 9, 2020 and November 23, 2020. While collecting data, social media tools (such as WhatsApp, Instagram, and Facebook) were used via online surveys. As a result, 1749 people who completed the questionnaires in two weeks, were literate, and used social media tools, were included in the study. The data of the study were collected using the "Sociodemographic Information Form," "Fear of COVID-19 Scale," and "COVID-19 Perceived Control Scale".

\section{Data Collection Tools}

Sociodemographic Information Form, developed by researchers in line with the literature, consists of a total of 10 questions concerning the socioeconomic, educational, and employment status of all participants as well as statements about COVID-19. ${ }^{[20-24]}$

Fear of COVID-19 Scale (FCV-19S) was developed by Ahorsu et al. (2020) to measure individuals' levels of fear caused by COVID-19. The validity and reliability study of the Turkish version of the scale was conducted by Ladikli et al. The fivepoint Likert type scale consists of seven items. The total score obtained from all items of the scale reflects the level of COVID-19 fear experienced by an individual. The highest and lowest scores that can be taken from the scale are 7 and 35 points, respectively. High scores from the scale mean that individuals experience high levels of fear of COVID-19. ${ }^{[20,24,25]}$ In the Turkish validity and reliability study of the scale, the Cronbach's alpha coefficient was reported as $0.86 .^{[24]}$ In the present study, the Cronbach's alpha coefficient of the scale was found to be 0.77 . 
COVID-19 Perceived Control Scale (CV-19PCS) was developed by Ekiz et al. (2020) to determine the perceived control of the COVID-19 epidemic. The 5-point Likert scale consists of three subdimensions (macro control, personal control, and inevitability) and 12 items. The lowest and highest scores that can be obtained from the scale are 12 and 60 points, respectively. Looking at the breakpoints of the scale, between 12 and 20 points are defined as a very low level of perceived control, while between 21 and 30 points, 31 and 40 points, 41 and 50 points, and 51 and 60 points are low, medium, high, and very high levels of perceived control, respectively. In the Turkish validity and reliability study of the scale, the Cronbach's alpha coefficient was specified as $0.72 . .^{[21]}$ In the present study, the Cronbach's alpha coefficient of the scale was found to be 0.64 .

\section{Data Analysis}

The data were analyzed with the IBM SPSS Statistics software (version 23), and compliance with normal distribution was examined using the Kolmogorov-Smirnovtest.Spearman's rank correlation coefficient was used to examine the relationship between scores that were not normally distributed. Mean, standard deviation, median, minimum and maximum values were used in the evaluation of the data. Independent twosample t-test was used to compare normally distributed data according to paired groups, and one-way analysis of variance was used for the comparison of normally distributed data according to three and more groups, and finally, the KruskalWallis test was used for comparing the data that were not normally distributed. The effect of the FCV-19S scores on the CV-19PCS total and subdimension scores was analyzed using linear regression analysis. The statistical significance level was taken as $\mathrm{p}<0.05$.

\section{Ethical Issues}

Prior to collecting research data, permission was obtained from the Social and Human Sciences Research Ethics Committee of a university, dated 04.11.2020 and numbered 01-11. All procedures were carried out in accordance with the ethical rules and the principles of the Declaration of Helsinki. Before individuals started to fill out the questionnaire, they were required to approve the informed consent form section explaining the purpose of the study. In this way, informed consent was obtained from all individuals who participated in the study.

\section{RESULTS}

The average age of participants included in the study was determined to be $32.9 \pm 10.7$. When the sociodemographic characteristics of participants and their FCV-19S total scores were evaluated, it was determined that there was a statistically significant difference between the FCV-19S total scores and the sociodemographic characteristics, such as gender, educational status, marital status, profession, family type, income status, place of residence, and status of contracting COVID-19. When the sociodemographic characteristics of participants and their CV-19PCS total scores were evaluated, it was determined that there was a statistically significant difference between the CV-19PCS total scores and the sociodemographic characteristics, such as educational status, marital status, family type, place of residence, status of employment during the COVID-19 pandemic and the status of contracting COVID-19 (Table 1).

The mean FCV-19S total score was found to be $21.7 \pm 5.8$. Regarding the CV-19PCS scores, the macro control, personal control, and inevitability subdimension mean scores were found to be $10.4 \pm 3.5,12.8 \pm 3.3$, and $11.7 \pm 3.7$ respectively, while the total mean score was found to be $35.6 \pm 5.6$ (Table 2).

There was a statistically significant relationship between the FCV-19S total score and the CV-19PCS macro control perception subdimension total score. The increase in the FCV-19S CS total score created a very weak decrease in the macro control perception total score. There was a statistically significant relationship between the FCV-19S total score and the CV-19PCS personal control perception total score. The increase in the FCV-19S total score resulted in a very weak increase in the personal control perception total score. There was a statistically significant relationship between the FCV$19 \mathrm{~S}$ total score and the CV-19PCS inevitability subdimension total score. The increase in the FCV-19S total score led to a very weak increase in the inevitability subdimension total score. No statistically significant relationship was found between the FCV-19S total score and the CV-19PCS total score (Table 3).

As the FCV-19S total score increased, the CV-19PCS macro control perception subdimension total score decreased, whereas, when the FCV-19S total score increased by one unit, the macro control subdimension total score decreased by 0.052 unit. As the FCV-19S total score increased, the CV19PCS personal control subdimension total score increased, whereas, when the FCV-19S total score increased by one unit, the personal control subdimension total score increased by 0.107 unit. As the FCV-19S total score increased, the CV19PCS inevitability subdimension total score increased, whereas, when the FCV-19S total score increased by one unit, the inevitability subdimension total score increased by 0.075 unit. There was no statistically significant effect of the FCV-19S total score on the CV-19PCS total score $(p=0.386)$ (Table 4).

\section{DISCUSSION}

The COVID-19 pandemic has had a profound effect across several countries worldwide, including Turkey. At the time of writing this study, the deep impact of the pandemic was still underway. As a result, the relationship between the fear created by the pandemic and the perceived control that can be used by individuals to cope with the pandemic were discussed in the light of limited findings acquired from the literature. 


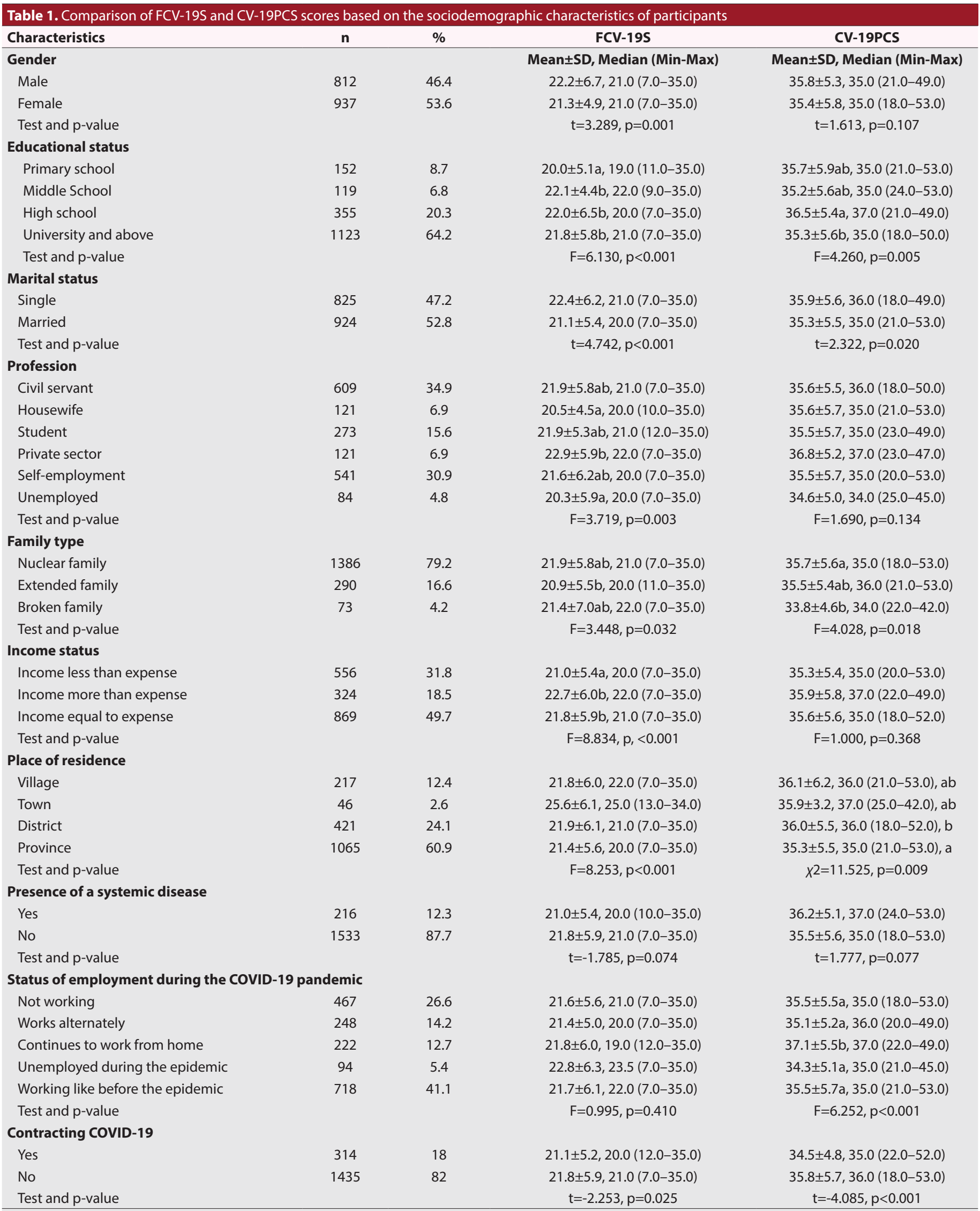




\begin{tabular}{|c|c|c|c|c|c|}
\hline & & $\mathrm{X}^{-} \pm \mathrm{SS}$ & Median & Minimum & Maximum \\
\hline \multicolumn{2}{|c|}{ FCV-19S } & $21.7 \pm 5.8$ & 21.0 & 7.0 & 35.0 \\
\hline \multirow{4}{*}{$\begin{array}{l}\text { U } \\
\frac{n}{1} \\
\frac{1}{3}\end{array}$} & $\begin{array}{l}\text { Macro Control } \\
\text { Subdimension }\end{array}$ & $10.4 \pm 3.5$ & 10.0 & 4.0 & 20.0 \\
\hline & $\begin{array}{l}\text { Personal Control } \\
\text { Subdimension }\end{array}$ & $12.8 \pm 3.3$ & 13.0 & 6.0 & 20.0 \\
\hline & $\begin{array}{l}\text { Inevitability } \\
\text { Subdimension }\end{array}$ & $11.7 \pm 3.7$ & 12.0 & 5.0 & 20.0 \\
\hline & Total & $35.6 \pm 5.6$ & 35.0 & 18.0 & 530 \\
\hline
\end{tabular}

Table 3. Examining the relationship between FCV-19S and CV-19PCS scores

\begin{tabular}{llcc} 
& & \multicolumn{2}{c}{ FCV-19S } \\
\cline { 3 - 4 } & Macro Control Subdimension & $\mathbf{~ r ~}$ & $\mathbf{p}$ \\
\hline \multirow{3}{*}{ CV-19PCS } & -0.119 & $<0.001$ \\
& Personal Control Subdimension & 0.171 & $<0.001$ \\
& Inevitability Subdimension & 0.115 & $<0.001$ \\
& Total & -0.039 & 0.101 \\
\hline r: Spearman's rank correlation coefficient & &
\end{tabular}

\begin{tabular}{|c|c|c|c|c|c|c|c|c|c|}
\hline The dependent variable & & Beta & s. error & $\begin{array}{c}\text { Non-standardized beta } \\
(95 \% \mathrm{Cl})\end{array}$ & $\mathbf{P}$ & $\mathbf{F}$ & $\mathbf{P}$ & $\mathbf{R 2}$ & Adjusted R2 \\
\hline \multirow{2}{*}{$\begin{array}{l}\text { CV-19PCS } \\
\text { Macro Control Subdimension }\end{array}$} & Constant & 11.542 & 0.322 & $(10.912-12.173)$ & $<0.001$ & \multirow{2}{*}{13.032} & \multirow{2}{*}{$<0.001$} & \multirow{2}{*}{0.007} & \multirow{2}{*}{0.007} \\
\hline & FCV-19S & -0.052 & 0.014 & $-0.086(-0.08--0.024)$ & $<0.001$ & & & & \\
\hline \multirow{2}{*}{$\begin{array}{l}\text { CV-19PCS } \\
\text { Personal Control Subdimension }\end{array}$} & Constant & 10.501 & 0.300 & $(9.912-11.089)$ & $<0.001$ & \multirow{2}{*}{64.402} & \multirow{2}{*}{$<0.001$} & \multirow{2}{*}{0.036} & \multirow{2}{*}{0.035} \\
\hline & FCV-19S & 0.107 & 0.013 & $0.189(0.081-0.133)$ & $<0.001$ & & & & \\
\hline \multirow{2}{*}{$\begin{array}{l}\text { CV-19PCS } \\
\text { Inevitability Subdimension }\end{array}$} & Constant & 10.047 & 0.344 & $(9.372-10.722)$ & $<0.001$ & \multirow{2}{*}{24.143} & \multirow{2}{*}{$<0.001$} & \multirow{2}{*}{0.014} & \multirow{2}{*}{0.013} \\
\hline & FCV-19S & 0.075 & 0.015 & $0.117(0.045-0.105)$ & $<0.001$ & & & & \\
\hline \multirow{2}{*}{$\begin{array}{l}\text { CV-19PCS } \\
\text { Total score }\end{array}$} & Constant & 35.996 & 0.514 & $(34.988-37.005)$ & $<0.001$ & \multirow{2}{*}{0.752} & \multirow{2}{*}{0.386} & \multirow{2}{*}{0.000} & \multirow{2}{*}{0.000} \\
\hline & FCV-19S & -0.020 & 0.023 & $-0.021(-0.065-0.025)$ & 0.386 & & & & \\
\hline
\end{tabular}

When the FCV-19S scores were analyzed according to the sociodemographic characteristics of participants, it was revealed that gender, educational status, marital status, profession, family type, income status, place of residence, and the status of contracting COVID-19 affected the fear of COVID-19, whereas the presence of a systemic disease and status of employment during the COVID-19 pandemic had no effect on the fear of COVID-19. Bakioğlu et al. (2020) studied the fear of COVID-19 and found that factors such as gender and having a chronic illness affected the fear of COVID-19, whereas educational status and place of residence had no effect on the fear of COVID-19. Memiş Doğan and Düzel (2020) examined the levels of fear and anxiety in the case of the COVID-19 pandemic. They deduced that gender, educational status, and profession had an effect on the fear of COVID-19. Gencer (2020) found that while gender and marital status affected the fear of COVID-19, the presence of a systemic disease and educational status did not affect the fear of COVID-19. Given these findings on sociodemographic characteristics in literature, the finding that gender, profession, and marital status had an impact on the fear of COVID-19 was supported by other studies. $[1,20,26,27]$ It can be concluded that these findings in literature supported the present study's findings. When educational status was evaluated, there were studies that supported the present study's finding and other studies reporting the opposite result. ${ }^{[1,20,26]}$ It can be said that this difference may have resulted from the fact that the studies were conducted in different periods of time during the pandemic. Bakioğlu et al. (2020) found that the place of residence did not affect the fear of COVID-19. ${ }^{[20]}$ However, in the present study, it was determined that place of residence was an effective factor contributing to the fear of COVID-19. Thus, it was determined that those living in provinces had less fear of COVID-19. It is thought that this situation may have resulted from easier access to services in provinces. In the study of Bakioğlu et al. (2020), there were findings that the presence of a systemic disease increased the fear of COVID-19. ${ }^{[20]}$ However, in the present study, no effect of a systemic disease on the fear of COVID-19 was found. It can be argued that this difference between the two studies stemmed from the difference in the sample groups studied. In the present study, it was found that family type had an effect on the fear of COVID-19. The lowest fear of COVID-19 mean score was found in the extended family. It can be thought that individuals in an extended family could receive support from their family elders without external support in matters such as child care, and they were less afraid of other working family members than they paid attention to individual measures. On the other hand, there was a higher mean score for the fear of COVID-19 in broken families. These individuals had to be in contact with more people as they had to get external support on issues, such as childcare and housekeeping. In this case, it may be argued that such individuals would have a greater fear of COVID-19, as it would increase the likelihood of contracting the disease. It was found that individuals with high income status had higher FCV-19S scores. This may be attributed to the fact that individuals with high income would have easier access to information and services, and they would be more aware of the seriousness of the situation. Considering the status of employment during COVID-19 pandemic, it was determined that those who were unemployed during the epidemic had higher mean scores for the fear of COVID-19, but it was not statistically significant. This may be due to the fact that unemployed individuals would believe that they would have difficulty in meeting their basic needs, and their immune 
systems might be weakened, resulting in them contracting COVID-19 more quickly and hardly recovering from it. Such individuals would also have difficulty in meeting their expenses including health expenses. It was found that the status of contracting COVID-19 had an effect on the fear of COVID-19. This finding may be due to the difficulty in overcoming the symptoms of the disease, occasional need for advanced health support, and fear of infecting their relatives.

When the CV-19PCS scores were analyzed according to the sociodemographic characteristics of participants, it was found that educational status, marital status, family type, place of residence, status of employment during the COVID-19 pandemic, and status of contracting COVID-19 affected the perceived control of COVID-19, whereas gender, profession, income status, and presence of a systemic disease did not affect the perceived control of COVID-19. Ekiz et al. compared the levels of health anxiety with the perceived control of the COVID-19 pandemic, and observed that gender has an effect on the perceived control. ${ }^{[21]}$ However, in the present study, it was determined that gender had no effect on the perceived control of COVID-19. This discrepancy may be due to fact that the perceived control levels of women and men may change depending on the differences in cultural life practices and gender roles. In the present study, it was determined that educational status had an effect on perceived control. The findings of Ekiz et al. (2020) support those of the present study. [21] In the present study, marital status was found to affect the perceived control of COVID-19. Since single individuals are not responsible for other people (such as children), it can be thought that they have a higher perceived control than married individuals. It has been found that the profession has no effect on the perceived control. However, family type was found to have an impact on perceived control of COVID-19. CV-19PCS score of individuals living in extended families in particular was found to be higher than groups in other family types. It can be argued that this was due to the higher social support individuals living in extended families could obtain. It was also determined that the place of residence affected the perceived control of COVID-19, and those living in villages had a higher perceived control than those living in provinces, districts, and towns. It can be said that COVID-19 perceived control scores of individuals living in villages were higher than those who resided in districts and provinces owing to reasons, such as villages are not very crowded and there are limited immigrants. It was found that the presence of a systemic disease state did not affect the perceived control of COVID-19, whereas individuals with a systemic disease had a moderate level of perceived control of COVID-19. It was found that the status of employment during the COVID-19 pandemic affected the perceived control of COVID-19, and those who continued to work from home had the highest perceived control of COVID-19 among other groups. It can be said that the perceived control of COVID-19 was higher than other groups, as individuals working from home did not have economic problems and did not come into contact with other people while going to work or in the workplace during the pandemic. It was determined that the status of contracting COVID-19 affected the perceived control of COVID-19. It was found that those who contracted COVID-19 had a lower level of perceived control of COVID-19 than those who did not contract COVID-19. This may be due to the fact that the individuals who contracted COVID-19 thought they had contracted COVID-19 as they were unable to control the pandemic conditions.

As the COVID-19 pandemic causes high loss of life in today's modern societies, fear can spread from an individual level to the social plane. In the present study, the FCV-19S total score of participants was above the median. Satıcı et al. (2020) and Duman (2020) reported results similar to those of the present study. ${ }^{[28,29]}$ When the perceived control of the COVID-19 pandemic was evaluated, it was found that participants had a moderate sense of control. In their study on perceived control, Zeng et al. (2020) stated that participants had a low level of perceived control. ${ }^{[30]}$ Their results partially supported the present study's results.

As perceived control acts as a protective factor against the psychological effects of COVID-19, there are studies in literature reporting that perceived control increases participants' ability to cope with stressors and changes the subjective experience of environmental stressors. ${ }^{[1,31,32]}$ According to findings of the present study, in the macro control subdimension of the COVID-19 Perceived Control Scale, any increase in the fear of COVID-19 created a slight decrease in the perceived control of COVID-19. However, any increase in the fear of COVID-19 resulted in a slight increase in the personal control and inevitability subdimensions of FCV-19S (Table 3). These findings of the present study partially support the literature findings. ${ }^{[15,31,32]}$ Despite these findings, when the relationship between FCV-19S and CV-19PCS total scores was evaluated, no correlation was found between the fear of COVID-19 and the perceived control of COVID-19.

In the literature, there are reports that perceived control plays a moderate role in the relationship between the severity of the pandemic and mental health problems. There are also reports that support the basic effects of perceived control on health, as well as those that state that perceived control has a buffering effect in adjusting the psychological consequences of individuals living in areas affected by the pandemic. ${ }^{[15,16,30-32]}$ In the present study, it was revealed that as the fear of COVID-19 increased, perceived control of the macro control subdimension of CV-19PCS decreased, but the total scores of the personal control and inevitability subdimensions increased. The results of the present study partially support the results of the previous studies, which indicate that perceived control has an effect on balancing of the psychological conditions experienced in the pandemic. [16,30,31] However, when the FCV-19S and CV-19PCS total mean scores were evaluated, no correlation was found between the perceived control of COVID-19 and the fear of COVID-19. 


\section{CONCLUSION}

As a result of this study conducted with the aim of determining the effect of the fear of COVID-19 on the epidemic control perceptions of individuals, it was determined that individuals' fear of COVID-19 and perceived control of COVID-19 were close to the median, whereas there was a partial correlation between the fear of COVID-19 and perceived control of COVID-19. However, results of the present study contribute significantly to the literature on understanding the psychological effects of the COVID-19 epidemic, such as fear and perceived control.

\section{Limitations}

As with any research, this study has some limitations. First onsite research could not be conducted due to the pandemic, and electronic tools were used for data collection. Individuals with no or limited access to these tools and illiterate could not be included in the scope of the study. Another limitation is that the answers given to the questionnaires are based on the self-report of individuals. In this case, some biases toward social desires may have been reported.

\section{ETHICAL DECLARATIONS}

Ethics Committee Approval: Ethics committee approval with the registration number $01-11$ and dated 04.11 .2020 was received from the Social and Human Sciences Research Ethics Committee, Tokat Gaziosmanpaşa University.

Informed Consent: All patients signed the free and informed consent form.

Referee Evaluation Process: Externally peer-reviewed.

Conflict of Interest Statement: The authors have no conflicts of interest to declare.

Financial Disclosure: The authors declared that this study has received no financial support.

Author Contributions: All of the authors declare that they have all participated in the design, execution, and analysis of the paper, and that they have approved the final version.

\section{REFERENCES}

1. Memiş Doğan M, Düzel B. Fear-anxiety levels in COVID-19. Turk Stud 2020;15:739-52.

2. Yıldız F. Epidemics in Anatolia at 19th century(the plague, the colera, the chicken pox and the malaria) and methods of struggles against epidemics. 2014, Dissertation, University of Pamukkale

3. Zhu H, Wei L, Niu P. The novel coronavirus outbreak in Wuhan, China. Global Health Res Policy 2020;56:1-3.

4. Perlman S. Another Decade, Another Coronavirus. New Engl J Med 2020;382(8):760-62.

5. WHO Coronavirus(Retrieved April 12, 2020, from World Health Organization(WHO) 2020. Available from https://www.who.int/healthtopics/coronavirus\#tab=tab_1.

6. Lau JT, Yang X, Pang E, Tsui HY, Wong E, Wing YK. SARS-related perceptions in Hong Kong. Emerg Infect Dis 2005;11(3):417-24.

7. Taylor MR, Agho KE, Stevens GJ, Raphael B. Factors influencing psychological distress during a disease epidemic:data from Australia's first outbreak of equine influenza. BMC Public Health 2008;8(347):1-13.
8. Zhang WR, Wang K, Yin L, et al. Mental Health and Psychosocial Problems of Medical Health Workers during the COVID-19 Epidemic in China. Psychother Psychosomat 2020;89(4);242-50.

9. Cava MA, Fay KE, Beanlands HJ, McCay EA, Wignall R. The experience of quarantine for individuals affected by SARS in Toronto. Public Health Nurs 2005;22(5):398-406.

10. Reynolds DL, Garay JR, Deamond SL, Moran MK, Gold W, Styra R. Understanding, compliance and psychological impact of the SARS quarantine experience. Epidemiol Infect 2008;136(7):997-1007.

11. Işıklı S. The psychological consequences of the COVID-19 outbreak and effective cooperation methods. 2020 Available from https://corona. hacettepe.edu.tr/wp-content/uploads/2020/06/Covid-19_psikolojik_ sonuclari_basa_cikma_yontemleri.pdf.

12. Kobayashi T, Jung SM, Linton NM, Kinoshita R, Hayashi K, Miyama T, Anzai A, Yang Y, Yuan B, Akhmetzhanov AR, Suzuki A, Nishiura H. Communicating the risk of death from novel coronavirus disease(COVID-19). J Clin Med 2020;9(2):580.

13. Skinner EA, A guide to constructs of control. J Pers Soc Psychol 1996;71(3):549-70.

14. Smith RE, Effects of coping skills training on generalized self-efficacy and locus of control. Journal of Pers Soc Psychol 1989;56(2):228 -33.

15. Li JB, Yang, A, Dou K, Cheung, R. Self-control moderates the association between perceived severity of coronavirus disease 2019(COVID-19) and mental health problems among the chinese public. Int J Environment Res Public Health 2020;17(13):4820.

16. Li JB, Yang A, Dou K, Wang LX, Zhang MC, Lin XQ. Chinese public's knowledge, perceived severity, and perceived controllability of COVID-19 and their associations with emotional and behavioral reactions, social participation, and precautionary behavior:a national survey. BMC Public Health 2020;20(1):1589.

17. Ferguson SJ, Goodwin, AD. Optimism and well-being in older adults:the mediating role of social support and perceived control. Int J Aging Hum Develop 2010;71(1):43-68.

18. Hofmann W, Luhmann M, Fisher RR, Vohs KD, Baumeister, RF. Yes, but are they happy? Effects of trait self-control on affective well-being and life satisfaction. J Pers 2014;82(4):265-77.

19. Çırakoğlu OC. The investigation of swine infl uenza(H1N1) pandemic related perceptions in terms of anxiety and avoidance variables. Turk $J$ Psychol 2011;26(67):49-64.

20. Bakioğlu F, Korkmaz O, Ercan H. Fear of COVID-19 and positivity:mediating role of intolerance of uncertainty, depression, anxiety, and stress. Int J Mental Health Addict 2020;1-14.

21. Ekiz T, llıman E, Dönmez E. Comparison of health anxiety level and control perception of COVID-19. Int J Health Management Strategies Res 2020;6(1):139-54.

22. Rubin GJ, Wessely S. The psychological effects of quarantining a city. BMJ 2020;m313.

23. Özdin S, Bayrak Özdin Ş. Levels and predictors of anxiety, depression and health anxiety during COVID-19 pandemic in Turkish society:The importance of gender. Int J Soc Psychiatry 2020;66(5):504-11.

24. Ladikli N, Bahadır E, Soft F, Akkuzu H, Karaman G, Türkkan Z. The realiability and valıdıty of Turkısh version of corona virus anxiety scale. Int J Soc Sci 2020;3(2):71-80.

25. Ahorsu DK, Lin CY, Imani V, Saffari M, Griffiths MD, Pakpour AH. The fear of COVID-19 scale:Development and initial validation. Int J Ment Health Addict 2020;1-9.

26. Gencer N. Coronavirus(COVID-19) fear of individuals during the pandemia:Çorum sample. Int J Soc Sci Acad 2020;4:1153-73.

27. Reznik A, Gritsenko V, Konstantinov V, Khamenka N, Isralowitz R. COVID-19 Fear in Eastern Europe:Validation of the Fear of COVID-19 Scale. Int J Ment Health Addict 2020;1-6.

28. Satici B, Saricali M, Satici SA, Griffiths MD. Intolerance of Uncertainty and Mental Wellbeing:Serial Mediation by Rumination and Fear of COVID-19. Int J Ment Health Addict 2020;1-12.

29. Duman N. COVID-19 fear and intolerance to uncertaınty in university students. J Soc Sci 2020;4(8):426-37. 
30.Zheng L, Miao M, Gan Y. Perceived Control Buffers the Effects of the COVID-19 Pandemic on General Health and Life Satisfaction:The Mediating Role of Psychological Distance. Appl Psychol Health and Wellbeing 2020;12(4):1095-114.

31. Alonso-Ferres M, Imami L, Slatcher, RB. Untangling the effects of partner responsiveness on health and well-being:The role of perceived control. J Soc Personal Relationships 2020;37(4):1150-71.

32. Lachman ME. Perceived control over aging-related declines. Curr Direct Psychol Sci 2006; 15(6):282-6. 